\title{
INVESTIGATION OF SAFETY AND QUALITY PARAMETERS OF GRANULATED FILLERS
}

\author{
Nataliya Grynchenko \\ Department of Meat Processing Technologies ${ }^{1}$ \\ tatagrin1201@gmail.com \\ Olga Tishchenko \\ Department of Bread, Confectionery, Pasta and Food concentrates Technology ${ }^{1}$ \\ olgapyvovarova52@ukr.net \\ Olga Grynchenko \\ Department of Food Technologies in the Restaurant Business ${ }^{1}$ \\ grinoly@gmail.com \\ Pavel Pyvovarov \\ Department of Food Technologies in the Restaurant Business ${ }^{1}$ \\ pcub@ukr.net \\ ${ }^{1}$ Kharkiv State University of Food Technology and Trade \\ 333 Klochkivska str., Kharkiv, Ukraine, 61051
}

\begin{abstract}
Within the conducted studies there were highlighted urgent questions of introducing the management system of quality and safety of food products. Quality and safety parameters that determine the notion of food product quality have been established by analyzing the normative and legislative base.

There were studied quality parameters of granulated fillers that are structured systems of the ball-like form with diameter (3...7) $\cdot 10^{-3} \mathrm{~m}$ and are characterized with a plastic, a bit crumbling consistence. Granules may be used as fillers for milk and sour-milk products, cheeses, ice-cream, dessert products, confectionary ones, beverages, salads, culinary floury products. The organoleptic quality evaluation of the products was realized by the descriptive (qualitative) method and by the profile analysis one (quantitative). Each organoleptic parameter (consistence, taste, smell and so on) is presented as a totality of components (descriptors), evaluated by quality, intensity and manifestation order. A characteristic of organoleptic parameters with intensity scales of separate signs is presented as profile diagrams. The complex organoleptic index that is $4.89 \ldots 4.95$ points has been determined. Basic physical-chemical properties of the new products were studied. It has been determined, that the content of main nutritive substances in the composition of fillers is: proteins $3.4 \ldots 7.2 \%$, lipids $-2.5 \ldots 6.5 \%$, total carbohydrates $7.8 \ldots 13.2 \%$, mineral substances $0.25 \ldots 1.12 \%$, that allow to pose fillers as products with the high food value.

Safety parameters of the granulated fillers were studied - microbiological and toxicological ones, and also the content of mycotoxins and antibiotics. It has been proved, that the new products fully correspond to established norms by these parameters. The study of microbiological indices of the new products has proved the content of viable lactate bacteria in the fillers in amount $3 \cdot 10^{8} \ldots 1 \cdot 10^{7} \mathrm{CFU}$ in $1 \mathrm{~g}$ of a product and the absence of the pathogenic and conventionally pathogenic microflora. The expert evaluation of safety of the granulated fillers as to the content of food supplements in their composition allows to make a conclusion about the correspondence of the developed products to international legislative requirements. It has been proved, that the storage term of new products is 90 days at temperature $1 . .6{ }^{\circ} \mathrm{C}$ and relative air humidity no more $75 \%$.
\end{abstract}

Keywords: granulated fillers, quality parameters, safety, organoleptic properties, microbiological and toxicological parameters.

DOI: $10.21303 / 2504-5695.2020 .001208$

\section{Introduction}

According to scientists, XXI century may become one of quality and safety. The international experience testifies that setting the problem of quality and food safety at the level of national idea allows not only to overcome the economic crisis, but to occupy leading positions at the world market.

Taking into account permanent crisis phenomena in economy, food industrial enterprises face an especially urgent question to provide the development and stable position at the food 
market. Under these conditions, quality and safety of food products become urgent and are most important competitiveness indicators of enterprises of this branch [1].

Questions of theory and practice of development, implementation and functioning of systems of quality and safety management were reflected in works [2-5]. But they include mainly general instructions and recommendations that have a concrete realization depending on type, capacity, branch belonging, food products assortment, technological production process peculiarities.

Quality in the wide sense determines satisfaction of consumer's expectations. That is quality parameters of a food product must correspond to consumers' expectation and satisfy their needs [6, 7].

But the quality of food products is not constant. It changes both during the technological production process and at storage. It determines a necessity of monitoring of quality parameters of a product during the whole cycle: from the beginning of production to the end of storage terms.

Taking into account the studied question, it must be noted, that in certain cases food products' safety is influenced by dangerous factors. In particular, food products and raw materials, containing toxic substances, unhealthy microorganisms, hormonal preparations, prohibited food supplements, harmful admixtures and so on, may be dangerous for human health and life.

The products' quality forms at the expanse of their ability to satisfy different consumers' needs. Thus, the products' quality may be in the sphere of satisfying the organism's need in nutritive substances and energy, determined by the food and energetic value of a product. The quality may be also determined by a technological degree of a product that is its ability to manifest its properties at processing [8]. An unambiguous quality factor is product's stability during the whole storage term. A high-quality product must at the same time have certain esthetical and economic characteristics.

Taking into account the development and implementation of the new products - granulated fillers - it is important to take into account possible risks and to conduct the monitoring of quality and safety parameters already at designing, developing models of the composition and technological process. Applying aspects of guaranteeing quality and safety of the new products at the stage of their development provide:

- correspondence of raw materials to requirements of existent normative documents by quality and safety parameters;

- market operator's possession of normative and technological documents, regulating quality and safety parameters of the products - technical conditions, technological instructions, recipes, technological card;

- maintenance of food production, taking into account established technological parameters;

- operational control of technological production parameters, evaluation of intermediate semi- and ready products by organoleptic, physical-chemical, microbiological and toxicological parameters (according to plans-graphs of a market operator);

- support of necessary conditions of storage and transportation of a product;

- informing a consumer about food product's properties by marking data, indicating the food value, storage conditions, storage term, consumption conditions after opening the hermetic package and so on.

So, appearance of new food products at the consumption market needs a detail study of their quality and safety parameters, substantiation of storage terms and conditions, determination of the food value, expert evaluation of food products' safety, taking into account the content of heavy metals and radionuclides, food supplements, genetically modified organisms.

The aim of the studies, highlighted in the paper, is to determine quality and safety parameters of the granulated fillers, obtained by ionotropic gel creation. The following tasks must be solved for attaining the set aim:

- to study quality parameters of the granulated fillers - organoleptic, physical-chemical, food value and their changes in the technological course;

- to determine safety parameters of the granulated fillers - microbiological and toxicological, and their changes in the technological course;

- to carry out the expert evaluation of the composition of the granulated fillers for the correspondence to requirements of existent normative documents as to the content of food supplements;

- to substantiate storage terms and conditions of the granulated fillers. 


\section{Materials and Methods}

Research subjects were:

- sodium alginate (AlgNa) FD-157 with $\chi=0.58$ (made by «Danisco», Denmark; $\chi$ - ratio between hyaluronic and mannuronic acids);

- granules (of the model system «AlgNa-Ca»), produced on the base of AlgNa solutions at concentration 1.0...2.0\% and $\mathrm{CaCl}_{2}$ solution at concentration $\mathrm{Ca}^{2+} 7.0 \ldots 120.0 \mathrm{mg} / \%$;

- granulated fillers.

Both granules as model systems and fillers were obtained by introducing drops of the recipe mixture, based on sodium alginate, to the solution of chlorous calcium with further keeping during $(0.5 \ldots 60) \cdot 60 \mathrm{~s}$ and decanting.

The following research methods were used at the experimental works.

The total chemical composition of the granulated fillers was studied by the conventional methods: a mass share of dry substances and moisture - by drying, a content of total protein by kJeldahl method, a mass share of total carbohydrates and lactose - by the polarimetric method, mineral substances - by ashing.

A mass share of ionic calcium in the solutions was determined by the potentiometric method, using calcium-selective electrode [9]. The sorption capacity of sodium alginate was calculated by the difference between the content of ionic calcium in the solution and its amount after sorption.

An effort of separation of «AlgNa-Ca» model systems from the solution surface of calcium chloride was evaluated using torsion scales, on which hook the studied cylindrical samples were fixed by a plate with a wire. A yoke of the scales was regulated up to setting balance, at that a scale indicator was at the null position. A flat-bottomed cup was filled with the studied calcium chloride solution, put on a moving platform of the device, until the sample touched the solution. In the touching position the samples were kept during $10 \mathrm{~s}$, then the platform was put down slowly using a screw, and the value of force $F$ was fixed by the external round scale. The separation effort was calculated by the formula:

$$
S E=\frac{F}{S}
$$

where $S E$ - separation effort, $\mathrm{Pa} ; F$ - force value, by the device scale, N; $S$ - area of the sample cross, $\mathrm{m}^{2}$.

The increment value of granules' mass and amount of the moisture, released from granules, was determined by the weight method. The mixture for granulation and formed granules was weighted. The granule mass increment was determined in percents by the ratio of the difference of the determined masses to the granule mass. The amount of moisture, released from granules, was determined after their keeping during a certain term.

The effective viscosity of the samples was determined by the rotation viscosimeter VCS-0.2M (Fig. 1) [10].

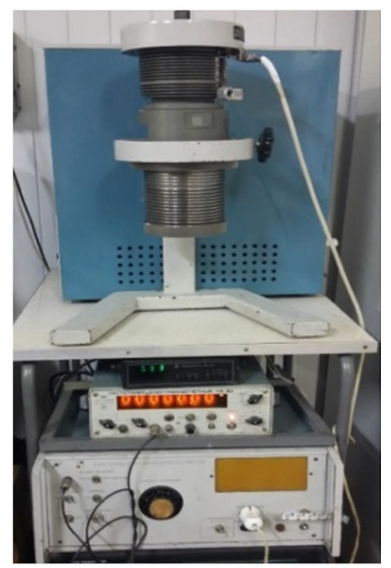

Fig. 1. Viscosimeter of constant strain VCS-0.2M 
The effective viscosity was found by the formula:

$$
\eta=k \cdot U \cdot T \cdot A
$$

where $\eta$ - effective viscosity, Pa.s; $k$ - constant of the knot, $\mathrm{Pa} / \mathrm{V} ; U$ - strain, $\mathrm{V} ; \mathrm{T}$ - rotation period, $\mathrm{s}$; A - кcoefficient of the measuring knot form.

The shift speed was determined by formula:

$$
\gamma=\frac{1}{T \cdot A}
$$

where $\gamma$ - shift speed, $\mathrm{s}^{-1}$.

Structural-mechanical properties of structured systems (reverse and irreversible deformation, instant elasticity module) were determined by modified scales of Kargin-Sogolova by studying the deformation of structured systems' compression under the effect of a chisel with a teflon nozzle [10]. The experimental data were expressed as curves of deformation kinetics (Fig. 2).

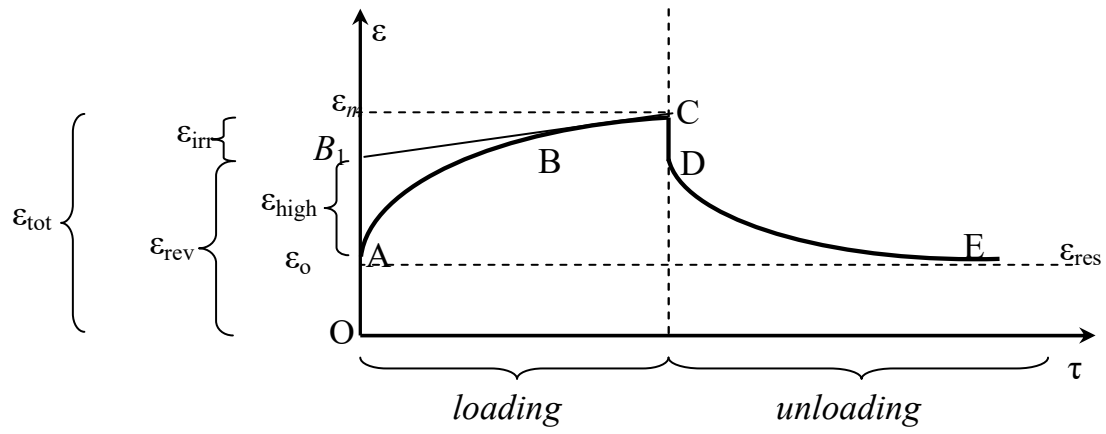

Fig. 2. Curve of the deformation development kinetics of the studied samples under the effect of applied strain (at loading and unloading)

The relative deformation of the structured systems was calculated by the formula:

$$
\varepsilon=\frac{z \cdot n}{h}
$$

where $\varepsilon$-deformation; $z$-division value of the microscope $z=10^{-3} \mathrm{~m} ; n$-divisions number in the microscope scale; $h$ - sample height, $\mathrm{m}$.

According to the data of the relative deformation curves, the instant elasticity module was determined by the formula:

$$
E_{e l}=\frac{m \cdot g}{S \cdot \varepsilon_{\hat{\imath}}}
$$

where $\mathrm{E}_{e l}$ - instant elasticity module, $\mathrm{Pa} ; \varepsilon_{0}$ - conventionally-instant deformation; $m$ - load mass, $\mathrm{kg} ; g$ - free fall acceleration, $\mathrm{m} / \mathrm{s}^{2} ; S$ - sample cross area, $\mathrm{m}^{2}$.

The active acidity of the studied samples was determined using pH-meter pH-150 MI (measuring technique, Russia) with the electrode system for measuring pH (Fig. 3).

The optic density of the samples was measured on the concentration photo-electric colorimeter CPC-2 (Russia) (Fig. 4).

The mass share of general mineral substances of epy granulated fillers was determined on the X-ray fluorescent analyzer ElvaX Light SDD (Elvatex, Ukraine) (Fig. 5).

The organoleptic evaluation of the samples was realized by the method of sensor analysis [11]. The caloric and energetic value of the products was determined by the calculating method by At- 
water coefficient, accepted that the energetic value of $1 \mathrm{~g}$ of protein is $4.0 \mathrm{kcal}(16.7 \mathrm{~kJ}), 1 \mathrm{~g}$ of fat $9.0 \mathrm{kcal}(37.7 \mathrm{~kJ}), 1 \mathrm{~g}$ of carbohydrates $-4.0 \mathrm{kcal}(15.4 \mathrm{~kJ})$.

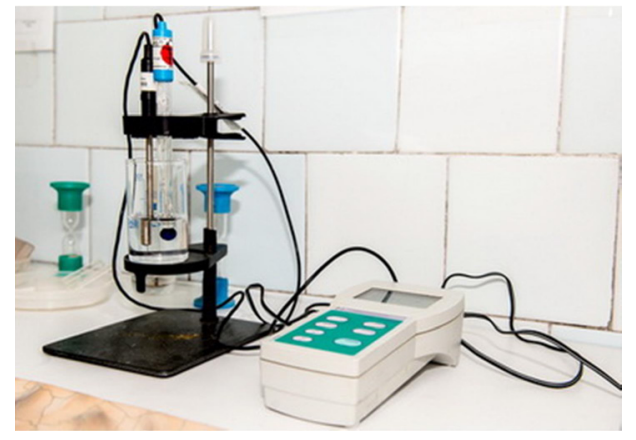

Fig. 3. pH-meter pH-150 MI

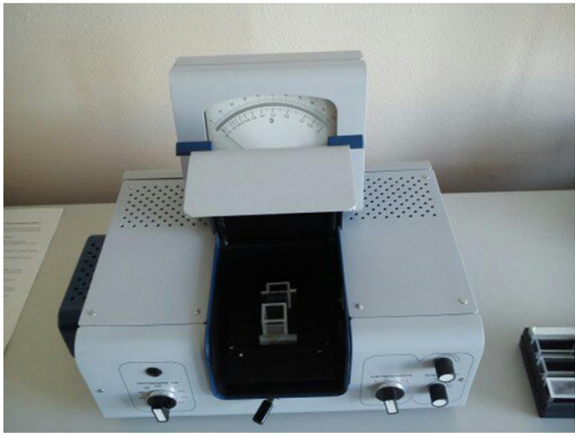

Fig. 4. Concentration photo-electric colorimeter $\mathrm{CPC}-2$
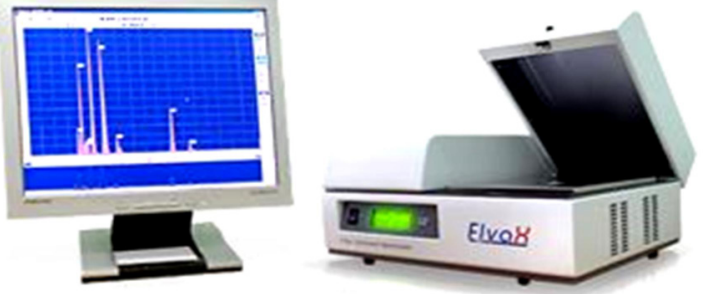

Fig. 5. X-ray fluorescent analyzer ElvaX Light SDD

Microbiological and toxicological parameters were studied by conventional methods [12, 13]. Permitted levels of food supplements in the granulated fillers were determined by [14].

The system approach methodology was realized within the study that allowed to combine diverse research methods. The technological systems were studied using the decomposition-aggregation method that combines two mutually connected processes - analysis (decomposition) and synthesis (aggregation). The combination of system analysis and synthesis allowed to solve the problem of rational functioning of systems, subsystems, separate elements, to establish their mutual connection within the united system.

\section{Results}

According to the research aim and tasks, the main quality and safety parameters of the granulated fillers were determined. Taking into account, that the developed fillers are new products at the consumption market, their chemical composition, organoleptic, physical-chemical, microbiological and toxicological parameters at storage were studied. Taking into account that the nomenclature of the developed fillers is rather high, the algorithm and volume of studying the mentioned parameters are presented on the example of granulated fillers, based 
on milk raw materials. In general this is a base for the complex evaluation of their quality and safety parameters.

Storage terms and conditions were studied, taking into account (1.2) coefficient of the reserve and aggravated temperatures, respectively.

The results of the organoleptic parameters of the granulated fillers are graphically presented as profiles of outlook and consistence, smell and taste (Fig. 6).

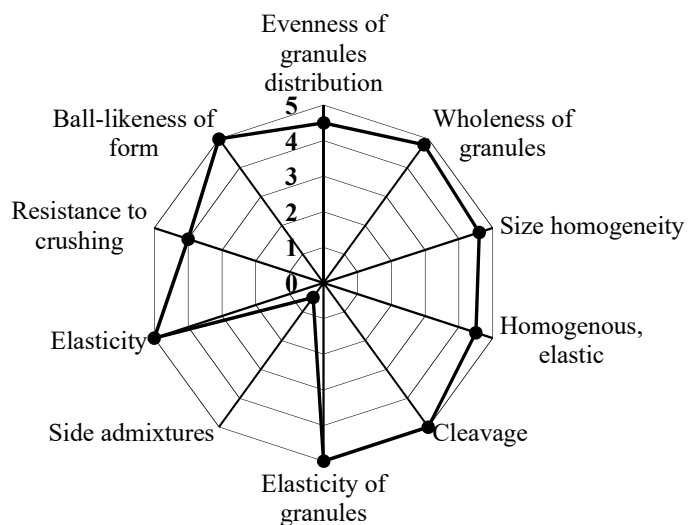

$a$

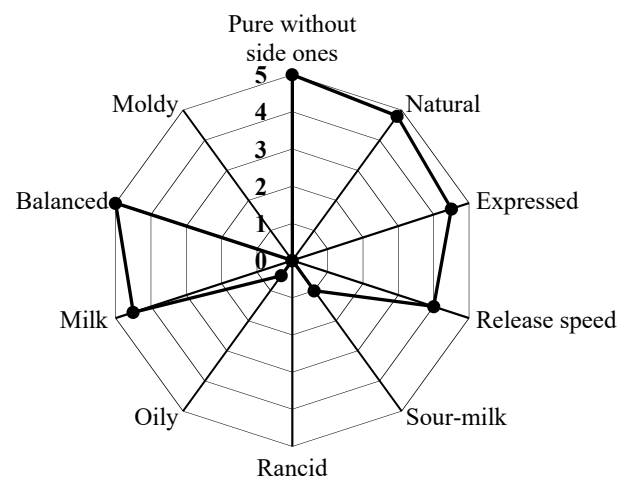

$c$
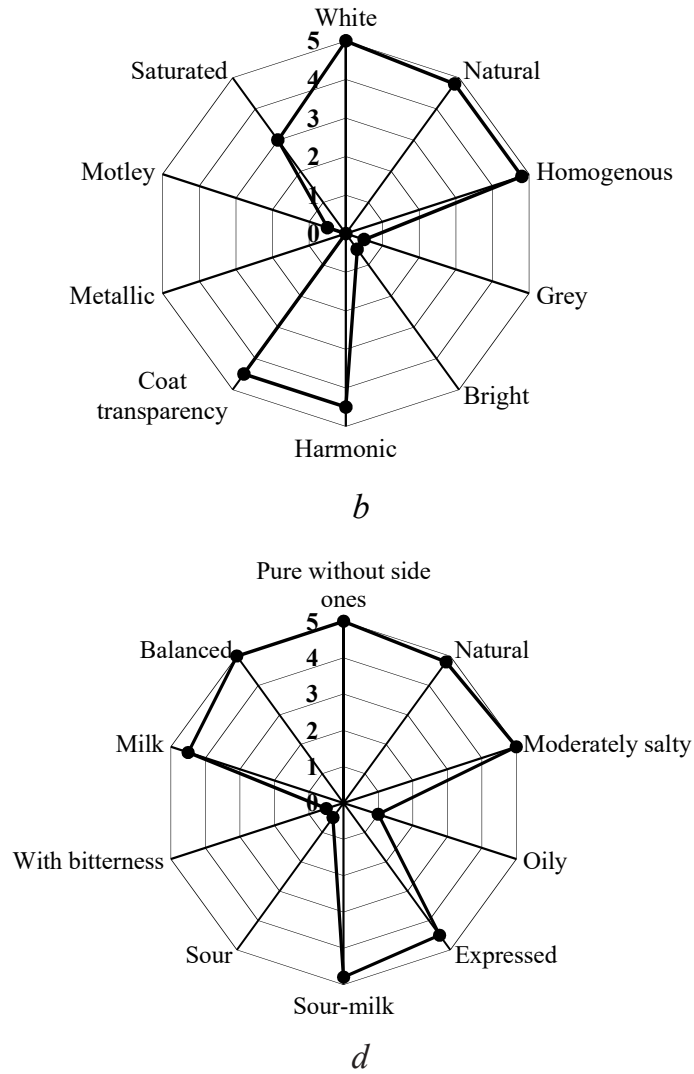

Fig. 6. Profilograms of the organoleptic evaluation of the granulated fillers, based on whey: $a$ - outlook and consistence; $b$ - color; $c$-smell; $d$ - taste

The expert evaluation of the organoleptic parameters has established that granulated fillers are structured systems of the ball-like form, homogenous by sizes, evenly distributed in a fill (depending on assortment - brine, sugar syrup, sauce); granule textures a bit differ by consistence. Thus, granulated fillers, based on whey, are characterized by the homogenous, plastic, easily dirtying consistence, milk ones - by the homogenous, plastic, a bit brittle or crumbling one, rather dense without whey separation. A granule is dense, transparent, without breaks. Experts assess the color of the new products as a homogenous, natural, typical for milk products - from white to lightcreamy. The absence of grey, metallic tints, motley fragments are fixed. The smell and taste are assessed as pure without side ones, expressed, balanced; the presence of individual smells is fixed; for whey granulated fillers - sour-milk, a bit salty; for milk ones - creamy. The total evaluation of milk and whey granulated fillers is $4.89 ; 4.95$ points respectively by the organoleptic parameters.

The chemical composition and physical-chemical parameters of the granulated fillers were studied (Table 1). It has been established, that the granulated fillers differ from each other by chemical composition. Thus, whey and milk fillers at mass share of dry substances $17.95 \pm 0.50 \%$ and $23.92 \pm 0.50 \%$ respectively include: proteins: from $3.4 \pm 0.1 \%$ to $7.2 \pm 0.1 \%$; lipids - from $2.5 \%$ to $6.5 \% \%$; total carbohydrates - from $7.8 \pm 0.1 \%$ to $13.2 \pm 0.1 \%$; mineral substances - from $0.25 \pm 0.01 \%$ to $1.12 \pm 0.05 \%$. 
Table 1

The chemical composition and physical-chemical parameters of the granulated fillers

\begin{tabular}{lcccc}
\hline \multirow{2}{*}{\multicolumn{1}{c}{ Parameter name }} & \multicolumn{3}{c}{ Parameter value during storage, days } \\
\cline { 2 - 4 } & \multicolumn{3}{c}{ Whey } & Milk \\
\cline { 2 - 4 } & Freshly-prepared & $18.31 \pm 0.5$ & $23.92 \pm 0.50$ & $24.34 \pm 0.5$ \\
\hline Mass share of dry substances, \% & $17.95 \pm 0.50$ & $3.5 \pm 0.1$ & $7.1 \pm 0.1$ & $7.2 \pm 0.1$ \\
Mass share of protein, \% & $3.4 \pm 0.1$ & $6.6 \pm 0.1$ & $2.5 \pm 0.1$ & $2.6 \pm 0.1$ \\
Mass share of fat, \% & $6.5 \pm 0.1$ & $7.95 \pm 0.1$ & $13.2 \pm 0.5$ & $13.4 \pm 0.5$ \\
Mass share of total carbohydrates (\%), & $7.8 \pm 0.1$ & $5.8 \pm 0.1$ & $3.9 \pm 0.1$ & $4.1 \pm 0.1$ \\
including: & $5.6 \pm 0.1$ & $2.15 \pm 0.05$ & $9.2 \pm 0.1$ & $9.3 \pm 0.1$ \\
- starch & $2.20 \pm 0.05$ & $0.26 \pm 0.03$ & $1.12 \pm 0.05$ & $1.14 \pm 0.05$ \\
- lactose & $0.25 \pm 0.01$ & $4.6 \pm 0.1$ & $6.3 \pm 0.1$ & $6.2 \pm 0.1$ \\
Mass share of mineral substances, \% & $4.7 \pm 0.1$ & $52.9 \pm 1.0$ & $52.0 \pm 1.0$ & $50.9 \pm 1.0$
\end{tabular}

There must be noted rather high protein content $(7.1 \ldots 7.2 \%)$ in the composition of milk fillers that allows to pose them as protein products. According to modern world trends of food products consumption, granulated fillers will be used for nutrition of the wide circle of consumers, especially by directions of sportification (for men) and fitnefication (for women).

The developed products' safety was estimated by determining the microbiological parameters (Table 2).

Table 2

The microbiological parameters of the granulated fillers $\left(t=8 \ldots 10^{\circ} \mathrm{C}\right)$

\begin{tabular}{|c|c|c|c|c|c|c|c|c|}
\hline \multirow{2}{*}{ Parameter name } & \multirow{2}{*}{$\begin{array}{l}\text { Permitted } \\
\text { levels }\end{array}$} & \multicolumn{7}{|c|}{ Parameter index for fillers (whey/milk) during storage, days } \\
\hline & & Freshly-prepared & 18 & 36 & 54 & 72 & 90 & 108 \\
\hline $\begin{array}{l}\text { Total amount of viable lactate bacteria, } \\
\text { CFU in } 1 \mathrm{~g} \text { of the product no less }\end{array}$ & $1 \times 10^{7}$ & $3 \cdot 10^{8} /-$ & $2 \cdot 10^{8} /-$ & $2 \cdot 10^{8} /-$ & $1 \cdot 10^{8} /-$ & $5 \cdot 10^{7} /-$ & $3 \cdot 10^{7} /-$ & $1 \cdot 10^{7} /-$ \\
\hline CBGB (coliforms) in $0,1 \mathrm{~g}$ & Not permitted & \multicolumn{7}{|c|}{ Not revealed } \\
\hline $\begin{array}{l}\text { Pathogenic and conventionally } \\
\text { pathogenic microorganisms, } \\
\text { including Sallmonella, } 25 \mathrm{~g}\end{array}$ & Not permitted & \multicolumn{7}{|c|}{ Not revealed } \\
\hline Staphylococcus ayreus, in $1 \mathrm{~g}$ & Not permitted & \multicolumn{7}{|c|}{ Not revealed } \\
\hline Fungi, CFU in $1 \mathrm{~g}$, no more & 50 & \multicolumn{7}{|c|}{ Not revealed } \\
\hline Listeria monocytogenes, in $25 \mathrm{~g}$ & Not permitted & \multicolumn{7}{|c|}{ Not revealed } \\
\hline
\end{tabular}

The developed fillers correspond to requirements [12]; colon bacillus group bacteria in $0.01 \mathrm{~g}$, fungi in $1 \mathrm{~g}$, pathogenic and conventionally pathogenic microorganisms, including ones of Salmonella genus and Listeria monocytogenes in $25 \mathrm{~g}$ have not been revealed in the fillers, the total amount of viable lactate bacteria in the whey filler is $3 \cdot 10^{8}$.

The study of the content of toxic elements, mycotoxins and antibiotics in the granulated fillers that are also determining characteristics, conditioning the new products' safety is presented (Table 3).

The obtained data allow to make a conclusion that the granulated fillers are safe products in the aspect of heavy metals, mytotoxins, hormonal preparations and antibiotics. We can see that the content of toxic elements doesn't exceed the established norms. Mytotoxins, hormonal preparations and antibiotics were not identified in the new products.

The analysis of data, presented in Table 1, allows to state that the mass shares of dry substances, protein, fat and mineral substances of the granulated fillers at storage during 108 days 
increase by $1.8 \ldots 2.3 \%$ comparing with the freshly-prepared samples. It is probably a result of partial dehydration of granule. Colon bacillus group bacteria in $0.01 \mathrm{~g}$, fungi in $1 \mathrm{~g}$, pathogenic and conventionally pathogenic microorganisms, including Salmonella genus bacteria and Listeria monocytogenes in $25 \mathrm{~g}$ were not revealed in the granulated fillers (Table 2). Taking it into account, the storage term of the products was established as no more 90 days at temperature $1 \ldots 6^{\circ} \mathrm{C}$ and air relative humidity no more $75 \%$.

Table 3

The toxicological parameters of the granulated fillers

\begin{tabular}{|c|c|c|c|}
\hline \multirow{2}{*}{ Parameter name } & \multirow{2}{*}{ Permitted levels, no more } & \multicolumn{2}{|c|}{ Content of components in the granulated fillers } \\
\hline & & Whey & milk \\
\hline \multicolumn{4}{|c|}{ Toxic elements, $\mathrm{mg} / \mathrm{kg}$} \\
\hline Lead & 0.1 & 0.05 & 0.003 \\
\hline Mercury & 0,005 & 0.003 & 0.002 \\
\hline Cadmium & 0.03 & 0.001 & 0.001 \\
\hline Arsenic & 0.05 & 0.001 & 0.001 \\
\hline Zinc & 5.0 & 1.0 & 1.5 \\
\hline Copper & 1.0 & 0.05 & 0.03 \\
\hline \multicolumn{4}{|c|}{ Mycotoxins, $\mathrm{mg} / \mathrm{kg}$} \\
\hline Aflatoxin $\mathrm{B}_{1}$ & Not permitted $(<0,001)$ & Not revealed & Not revealed \\
\hline Aflatoxin $\mathrm{M}_{1}$ & 0.0005 & Not revealed & Not revealed \\
\hline \multicolumn{4}{|c|}{ Hormonal preparations, mg/kg: } \\
\hline Diethylstilbestrol & Not permitted & Not revealed & Not revealed \\
\hline Estradiol $17 \beta$ & 0.0002 & Not revealed & Not revealed \\
\hline \multicolumn{4}{|c|}{ Antibiotics, un/g } \\
\hline Tetracycline group & $<0.01$ & Not revealed & Not revealed \\
\hline Penicillin & $<0.01$ & Not revealed & Not revealed \\
\hline Streptomycin & $<0.5$ & Not revealed & Not revealed \\
\hline
\end{tabular}

The expert evaluation of granulated fillers' safety as to the content of food supplements in their composition allows to make a conclusion about the correspondence of the developed products to the international legislative requirements (Table 4).

Table 4

The content of food supplements in the granulated fillers' composition

\begin{tabular}{ccccc}
\hline $\begin{array}{c}\text { Food supplement } \\
\text { name }\end{array}$ & E index & Maximal level, mg/kg & \multicolumn{2}{c}{ Content in fillers, mg/kg } \\
\cline { 3 - 5 } (according to SSU - H CODEX STAN 192) & whey & milk \\
\hline Modified corn starch & 1422 & In necessary amount & 56000 & $39000 /-$ \\
Carrageenan & 407 & In necessary amount 20000 & 7000 & $-/-$ \\
Xanthan gum & 415 & In necessary amount & 1000 & $1000 /-$ \\
Sodium alginate & 401 & In necessary amount 10000 & 3000 & $3000 / 3000$ \\
Calcium alginate & 404 & &
\end{tabular}

It has been established, that the maximal level of corn modified starch and xanthan gum is not regulated, it is possible to use them at the technological necessity; the content of carrageenan and sodium/calcium alginate is essentially lower than the maximal level $-7000 \mathrm{mg} / \mathrm{kg}$ and $3000 \mathrm{mg} / \mathrm{kg}$ respectively. 


\section{Conclusions}

1. Taking into account the requirements of existent legislative and normative documents, the quality and safety parameters of the granulated fillers in the technological course of their production were complexly studied. The organoleptic and physical-chemical parameters, chemical composition, food value, microbiological and toxicological parameters and their changes at storage during 102 days have been established. The correspondence of the new products to the requirement of actual Ukrainian legislation has been proved.

2. The expert evaluation of the organoleptic parameters of the new products has established that granulated fillers are structured systems of the ball-like form with the firm consistence, white - light cream color with the taste and smell, typical to a concrete assortment unit: whey sour-milk, moderately salty; milk - creamy. The total mark of the whey and milk fillers by the organoleptic parameters is $4.89 ; 4.95$ points, respectively.

3. The chemical composition and physical-chemical parameters of the granulated fillers were studied. It has been established, that depending on recipe composition, the mass share of dry substances varies within $17.95 \ldots 23.92 \%$, proteins $-3.4 \ldots 72 \%$; lipids $-2.5 \ldots 6.5 \%$, total carbohydrates - 7.8..13.2\%; mineral substances $-0.25 \ldots 1.12 \%$.

4. It has been experimentally proved, that the granulated fillers are safe products in the aspect of heavy metals, mytotoxins, hormonal preparations and antibiotics. The content of toxic elements is within the permitted values and doesn't exceed the established norms. Mytotoxins, hormonal preparations and antibiotics were not identified .The expert evaluation of granulated fillers' safety as to the content of food supplements in their composition allows to make a conclusion about the correspondence of the developed products to the existent legislative requirements.

5. Taking into account reserve coefficient (1.2) and aggravated temperatures, storage terms and conditions were studied. It has been proved, that the storage term of the new products is 90 days at temperature $1 \ldots 6^{\circ} \mathrm{C}$ and relative air humidity no more $75 \%$.

\section{References}

[1] Van der Vorst, J. G. A. J., Tromp, S.-O., Zee, D.-J. van der. (2009). Simulation modelling for food supply chain redesign; integrated decision making on product quality, sustainability and logistics. International Journal of Production Research, 47 (23), 6611-6631. doi: http://doi.org/10.1080/00207540802356747

[2] Bilska, A., Kowalski, R. (2014). Food quality and safety management. LogForum, 10 (3).

[3] Surkov, I. V., Kantere, V. M., Motovilov, K. Y., Renzyaeva, T. V. (2015). The development of an integrated management system to ensure the quality stability and food safety. Foods and Raw materials, 3 (1). 111-119. doi: http://doi.org/10.12737/11245

[4] Luning, P. A., Kirezieva, K., Hagelaar, G., Rovira, J., Uyttendaele, M., Jacxsens, L. (2015). Performance assessment of food safety management systems in animal-based food companies in view of their context characteristics: A European study. Food Control, 49, 11-22. doi: http://doi.org/10.1016/j.foodcont.2013.09.009

[5] Panghal, A., Chhikara, N., Sindhu, N., Jaglan, S. (2018). Role of Food Safety Management Systems in safe food production: A review. Journal of Food Safety, 38 (4), e12464. doi: http://doi.org/10.1111/jfs.12464

[6] Van Boekel, M. A. J. S. (2008). Kinetic Modeling of Food Quality: A Critical Review. Comprehensive Reviews in Food Science and Food Safety, 7 (1), 144-158. doi: http://doi.org/10.1111/j.1541-4337.2007.00036.x

[7] Lee, S. J., Jung, H. Y. (2010). Identification of quality attributes of university foodservice and factors required for the improvement of customer satisfaction: A case study using IPA model. Journal of the Korean Dietetic Association, 16 (3), $208-225$.

[8] Buckland, N. J., Dalton, M., Stubbs, R. J., Hetherington, M. M., Blundell, J. E., Finlayson, G. (2015). Associations between nutritional properties of food and consumer perceptions related to weight management. Food Quality and Preference, 45, 18-25. doi: http://doi.org/10.1016/j.foodqual.2015.04.009

[9] Lewis, M. J. (2010). The measurement and significance of ionic calcium in milk - A review. International Journal of Dairy Technology, 64 (1), 1-13. doi: http://doi.org/10.1111/j.1471-0307.2010.00639.x

[10] Horalchuk, A. B., Pyvovarov, P. P., Hrynchenko, O. O. (2006). Reolohichni metody doslidzhennia syrovyny i kharchovykh produktiv ta avtomatyzatsiia rozrakhunkiv reolohichnykh kharakterystyk. Kharkiv: KhDUKhT, 63.

[11] DSTU ISO 6658:2005. Doslidzhennia sensorne. Metodolohiia. Zahalni nastanovy. (ISO 6658:1985, IDT) (2006). Kyiv: Derzhspozhyvstandart Ukrainy, 26.

[12] Mikrobiolohichni kryterii dlia vstanovlennia pokaznykiv bezpechnosti kharchovykh produktiv (2012). Zatverdzheno nakazom MOZ Ukrainy No. 548. 19.07.2012. Available at: http://zakon0.rada.gov.ua/laws/show/z1321-12 Last accessed: 11.07.2018 
[13] Commission Regulation 466/2001 of 8 March 2001 fixing maximum levels for certain contaminants in foodstuffs. Available at: https://op.europa.eu/en/publication-detail/-/publication/89680896-d084-4f35-8340-13e8b4f59f08/language-en

[14] Kharchovi dobavky. Nomenklatura ta zahalni vymohy: DSTU-N CODEX STAN 192:2009 (2009). Kyiv: Ukrderzhspozhyvstandart Ukrainy, 246.

\title{
SUBSTANTIATION OF THE CHOICE OF FILLERS FOR COTTAGE CHEESE MASSES
}

\author{
Marina Samily $\boldsymbol{k}^{1}$ \\ m.samilyk@ukr.net \\ Anna Helikh ${ }^{1}$ \\ gelihsumy@gmail.com \\ Natalia Bolgova ${ }^{1}$ \\ bolgova_1981@i.ua \\ Taisia Ryzhkova \\ Kharkiv State Zooveterinary Academy \\ 1 Akademichna str., Mala Danylivka, Dergachivsky district, Kharkiv region, Ukraine, 62341 \\ rujkova.ua@gmail.com \\ Igor Sirenko ${ }^{1}$ \\ igorsirenko5@gmail.com \\ Oleg Fesyun ${ }^{1}$ \\ oleg.takert@gmail.com \\ ${ }^{1}$ Sumy National Agrarian University \\ 160 Gerasim Kondratyev str., Sumy, Ukraine, 40000
}

\footnotetext{
Abstract

The aim of this work is to justify the use of candied fruits as fillers in the production of curd and to study their influence on the quality indicators of the finished product. The article presents studies of the organoleptic, physicochemical, structural and mechanical properties of the curd masses depending on the type of fillers. Curd recipes have been developed with candied parsnip in the amount of $10 \%$, candied parsnip in the amount of $15 \%$, candied pumpkin in the amount of $10 \%$, candied pumpkin in the amount of $15 \%$. Experimental studies have determined the optimal dose of candied fruits from parsnip and pumpkin, which is $150 \mathrm{~kg}$ per $1000 \mathrm{~kg}$ of the product.

The chemical composition of pumpkin and parsnip is analyzed, the feasibility of using candied fruit from them as fillers is substantiated. In order to preserve the maximum amount of vitamins in candied fruit, a technology for their production has been developed, including cooking in sugar syrup using low temperatures $\left(60^{\circ} \mathrm{C}\right)$ and further drying by the convection-vacuum method at a temperature of $50{ }^{\circ} \mathrm{C}$.

It has been established, that all types of fillers that took part in the experiments do not adversely affect the physicochemical and rheological properties of the curd mass. It has been proven, that candied parsnip and pumpkin positively affect the density of the curd mass structure and provide the plastic structure of the product.

Keywords: cottage cheese, cottage cheese, candied fruit, parsnip, pumpkin, recipe, vitamins, carotene, structure density, sucrose content.
} 